\title{
Finnish records of discomycetes: type studies on some Karsten species
}

\author{
SEPPO HUHTINEN
}

\begin{abstract}
HUHTINEN, S. 1994: Finnish records of discomycetes: type studies on some Karsten species. - Karstenia 34: 5-12. ISSN 0453-3402

Peziza virella P. Karst. is shown to be conspecific with Amicodisca brdensis (Velen.) Svr. and a new combination, Amicodisca virella (P.Karst.) Huhtinen, is proposed. Peziza sordidula P.Karst. is placed in the genus Pseudohelotium Fuckel and is shown to offer an earlier name for Belonium vernale Velen. The genus Aleuriella (P.Karst.) P.Karst. is considered as distinct from Mollisia (Fr.) P.Karst. Aleuriella personata (P.Karst.) P. Karst. may offer an earlier name for Mollisia psilopezizoides Svrček. Peziza perforata P. Karst. is shown to be a synonym of Tarzetta catinus (Holmsk. : Fr.) Korf \& Rogers. Typification for each of the treated taxa is clarified.
\end{abstract}

Key words: Discomycetes, Karsten, taxonomy, type studies

Seppo Huhtinen, Herbarium, University of Turku, FIN-20500 Turku, Finland

Some interesting discomycetous types have been encountered during the ongoing project on P. A. Karsten's herbarium in $\mathrm{H}$.

These are discussed below with detailed illustrations. Karsten's descriptions have been supplemented with microscopic details. As well, the typifications are scrutinized in detail, as Karsten's herbarium is complex in containing not only original but doubtfully original, vaguely cited and split specimens. The following abreviations are used: $\mathrm{CB}$ (cotton blue in lactic acid), CR (ammoniacal Congo red), MLZ (Melzer's reagent), FFE (Karsten, P. A. 18611870: Fungi Fenniae Exsiccati).

Amicodisca virella (P.Karst.) Huhtinen, comb. nov. - Fig. 1.

Peziza virella P.Karst., Fungi Fenniae Exsiccati, fasc. 7: 627. 1867. - Helotium virellum (P.Karst.) P.Karst., Not.
Sällsk. Fauna Flora Fennica Förh. 11: 241, 1870. Ombrophila virella (P.Karst.) P.Karst., Bidr. Kännedom Finlands Natur Folk 9: 94. 1871. — Chlorospleniella virella (P. Karst.) P.Karst., Acta Soc. Fauna Flora Fennica 2: 141. 1885. - Coryne virella (P. Karst.) Sacc., Syll. Fung. 8: 645. 1889. - Corynella virella (P.Karst.) Boud., Hist. classific discom. Europe: 99. 1907. - Type: [Finland. Etelä-Häme: Tammela] Mustiala, på alved [on decorticated wood of Alnus], juni [VI.] 1867 [P. Karsten] FFE 627 (H, lectotype; selected here).

Dasyscypha brdensis Velen., Monogr. Discom. Bohem. 238. 1934. - Amicodisca brdensis (Velen.) Svrček, Česka Mykol. 41: 16. 1987. — Type (Svrček 1987a: 17): [Czech Republic.] Bohemia meridionalis, Trebon in pratis uliginosis "Mokre Louky" dictis, ad trunculum Salicis cinereae, 18.IX.1982 J. Kubička \& M. Svrček (PRM 842732, neotype; not examined).

The species was first described in Karsten's exsiccatum with the following characteristics: small, sessile apothecia with greenish hairs and pallid olivaceous disc, spores elongate-fusoid, 13- 
$19 \times 4-5 \mu \mathrm{m}$. The collection date given on the printed exsiccatum label is June 1867. Somewhat later (Karsten 1869) the description was emended and a second collection locality cited. The description in Mycologia Fennica (Karsten 1871) was practically identical. Ascal reaction was then given as MLZ-, which, however, is not the case.

In 1885 Karsten placed $P$. fennica P.Karst., $P$. stemmata P.Karst. and $P$. virella in the new genus Chlorospleniella P.Karst. Clements and Shear (1931) later lectotypified the genus with $P$. fennica, the first species of the three listed by Karsten. This choice was not discussed in any way and the mechanical method of lectotypification cannot be ruled out. There is, however, no good nomenclatural reason to overturn the choice. More unfortunate is that no material of the lectotype species is left in either H or S. P. fennica was treated as a nomen dubium by Dixon (1974). The second species, P. stemmata, is a Mollisia (Dixon 1974).

The genus Amicodisca has been briefly treated by Huhtinen (1990) where the delimitation from Hyaloscypha Boud. was discussed. Although original material was not studied, the identity with Karsten's material cannot be doubted. Svrček (1987a) illustrated the hairs as aseptate, but the inconspicuous septa could have passed unnoticed. The affinity to Dematioscypha Svrček was discussed, but Dennisiodiscus Svrček. would seem to be a more closely related genus. The differentiating characters can be found in the more dermataceous excipulum and different ecology of Dennisiodiscus.

The substrate in the other two specimens in $\mathrm{H}$ looks identical with that in FFE 627. Apparently Karsten collected this rare species twice from the same trunk, as these specimens are dated June 1866, i.e. a year earlier than the date given in the protologue in FFE. Excluded by the protologue, they cannot constitute type material, but may be considered as original material, possibly at hand when the protologue was made. So far, the species has been reported only for deciduous wood; this was also the case in the three additional collections in TAA studied earlier (Huhtinen 1990).

Additional specimes examined

Finland. Etelä-Häme: Tammela, Mustiala, 29.VI.1866 $P$. Karsten 3469, 3470 (H).

Pseudohelotium sordidulum (P.Karst.) Huhtinen, comb. nov. - Fig. 2.

Peziza sordidula P.Karst., Fungi Fenniae Exsiccati, fasc. 8: 751. 1868. - Trochila sordidula (P.Karst.) P.Karst., Not.
Sällsk. Fauna Flora Fennica Förh. 11: 244. 1870. Mollisia sordidula (P.Karst.) P.Karst., Bidr. Kännedom Finlands Natur Folk 9: 193. 1871. - Type: [Finland. Etelä-Häme: Tammela] Mustiala, pả tallved [on decorticated wood of Pinus] [26] Sept. [1868 P. Karsten] FFE 751 (H, lectotype, selected here; 3555 and 3556, isolectotypes, examined).

Belonium vernale Velen., Monogr. Discom. Bohem.: 181. 1934. - Pseudohelotium vernale (Velen.) Svrček, Česka Mykol. 41: 93. 1987. - Type (Svrček 1987b: 93): [Czech Republic.] Bohemia centralis, Radotín prope Pragam, ad squamam strobilinam Pini nigrae, 12.III.1927 Velenovsky (PRM 148822b, lectotype; not examined).

The species was described in Karsten's exsiccatum with a rather short diagnosis, and a more detailed description was published the following year (Karsten 1869). Two subsequent treatments in which the species was combined anew, offer no additional information except the statement that the species was found only once. Indeed, the fungi and substrate in the three packets in herb. $\mathrm{H}$ are identical suggesting that they are from the same collection site. None of the fragments was solely included by the protologue (Art. 7.3. Note 1.). Hence, the material is best considered syntypic and a lectotype needs to be selected.

Karsten's observations agree well with the material. The spores are mostly 3 -septate and have prominent acyanophilous guttulae. The outermost margin is composed of firm-walled, cylindrical hyphal ends. In $\mathrm{KOH}$ one can clearly observe the thin-walled, clavate hyphal ends which more or less cover the flanks and almost extend to the margin. In $\mathrm{KOH}$ they bear prominent, brown encrustation, whereas in CB they are perfectly smooth-walled. These are the cells about which Svrček (1987b) wrote "similarly encrusted are the elliptical cells of which the marginal hyphae grow out".

Svrček's (1987b) illustration and description of Pseudohelotium vernale is in close agreement. The sole difference is that the spores in the Czech material are reported as shorter, reaching only 20 $\mu \mathrm{m}$ in length. Svrček notes, however, that the spores he measured were juvenile. In Karsten's material the average size for 10 spores (in CB) is $23.5 \mathrm{x}$ $3.3 \mu \mathrm{m}$. Like Karsten's the Czech material was collected on coniferous substrate, but the vernal fruiting is different. Dennis (1950) illustrated type material of the species, referring it to Orbiliopsis Höhn., but without formally proposing a new combination. Later (Dennis 1971), when the taxa in Orbiliopsis were transferred to Phaeohelotium Kanouse, P. sordidula was not included. The new com-bination proposed above 


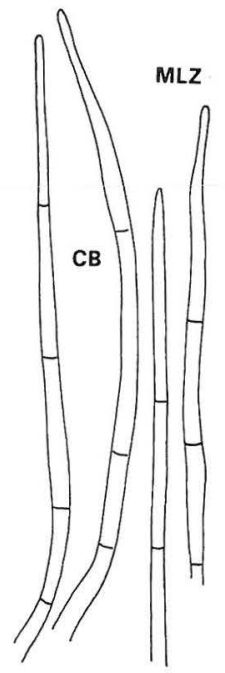

a
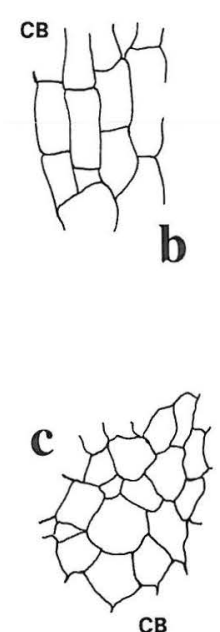

CB
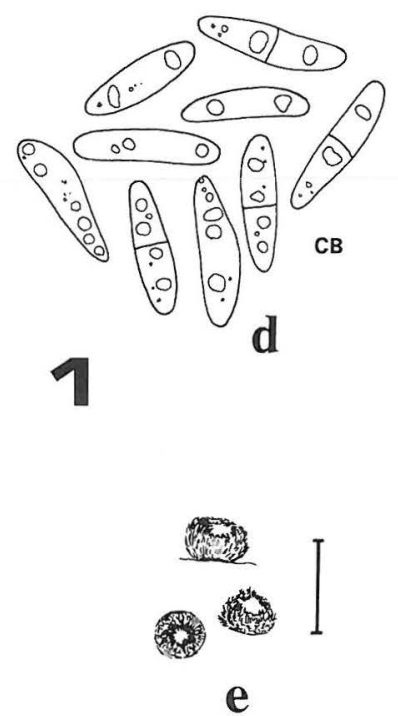

e

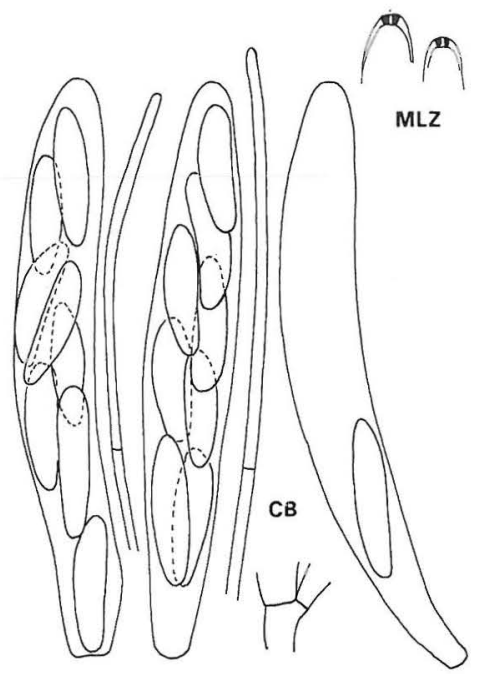

f
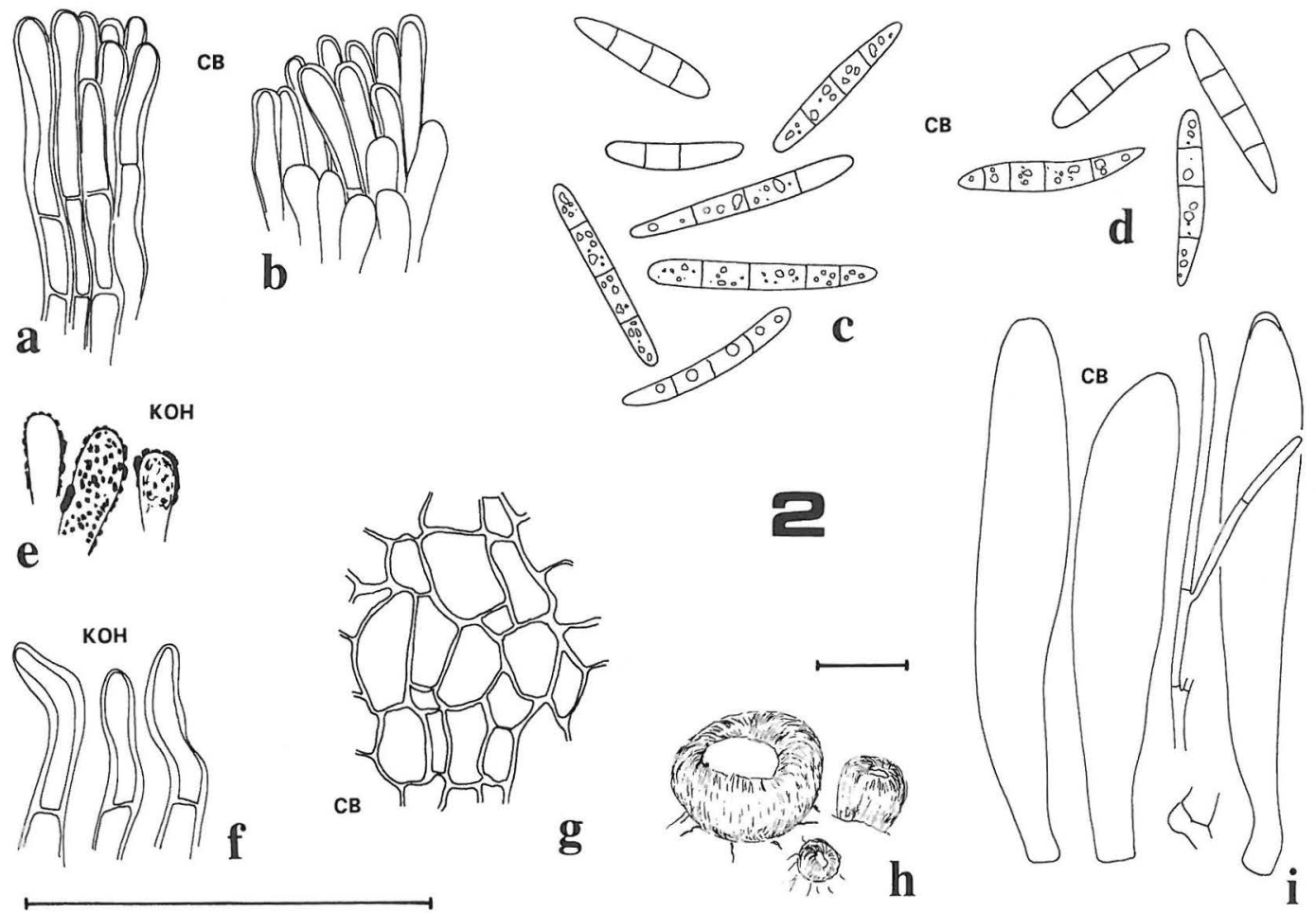

Figs. 1-2. Types of Amicodisca virella and Pseudohelotium sordidulum, scale $50 \mu \mathrm{m}$, for apothecia $100 \mu \mathrm{m}$. -1 : Amicodisca virella, lectotype. a) marginal hairs, b) ectal excipulum from medial flank area, c) ectal excipulum from basal area, d) spores, e) dry apothecia, f) asci and paraphyses. - 2: Pseudohelotium sordidulum, lectotype (b, d), isolectotype (No. 3555; a, c, e-i). a, b) marginal hyphae, c, d) spores, e) hyphae below the margin, f) marginal hyphae, g) ectal excipulum from medial flank area, h) dry apothecia, i) asci and paraphysis. 
follows the generic placement suggested by Svrček (1987b).

Le Gal (1939) described a new forma of Mollisia sordidula. The spores were illustrated as one-septate and occasional, two- to three-septate spores were mentioned. The spores were drawn wider than in the present material, but apparently they are illustrated in living condition, which may account for the difference (Baral 1992). The asci, however, are twice as long as those in the present material. The conspecificity with present material remains doubtful.

\section{Aleuriella personata (P.Karst.) P.Karst. - Fig. 3.}

Peziza personata P.Karst, Not. Sällsk. Fauna Flora Fennica Förh. 10: 154. 1869. - Aleuriella personata (P.Karst.) P.Karst., Not. Sällsk. Fauna Flora Fennica Förh. 11: 243. 1870. - Mollisia personata (P.Karst.) Sacc., Syll. Fung. 8: 341. 1889. - Pyrenopeziza personata (P. Karst.) Boud., Hist. Classific. Discom. Europe: 133. 1907. - Type: [Finland. Etelä-Häme:] Mustiala, på björkbark [on cortex of Betula] [P. Karsten] FFE 749 (UPS, lectotype, selected here; $\mathrm{H}$, isolectotype, examined).

The protologue (Karsten 1869) does not refer to a specific collection. The ecology was given as "inner cortex of Betula", which excludes specimen 3359 (on twigs) from lectotypification. Specimens 3360 and 3361 were collected in 1869 , the same year the protologue was published. As the preface for "Monographia" is dated to summer 1868 , these two specimens are unlikely to be original material. Specimens 3362 and 3363 are also excluded from being original material by their later collection dates. Two of the syntypes examined were empty (3358 and FFE 749 in H). The exsiccatum in UPS bears ca. ten apothecia and is suitable for lectotypification. The ample specimen 3363 would be best suited for any restudy of Karsten's material.

The species was described by Karsten in 1869 as the sole member of his section Aleuriella in Peziza, the characteristics of which were shortly stipitate, glabrous, waxy and soft apothecia, subellipsoid spores with one large guttula, filiform paraphyses, and the corticolous habit. A year later this section was raised to generic rank (Karsten 1870) and a second species, Tympanis frangulae Fr., was included. Simultaneously Karsten synonymized his earlier concept (Karsten 1871) of Peziza lividofusca Fr. with the present species. Karsten's material in $\mathrm{H}$, named "Personataria lividofusca" is, indeed, conspecific with his later collections of $P$. personata. The description by Fries (1823) is, however, too vague to decide on synonymy. No material of this species exists in Fries' herbarium in $\mathrm{S}$.

Aleuriella (P.Karst.) P.Karst. appeared again as a separate genus in "Mycologia fennica 1." (Karsten 1871). Sessile habit, brownish excipulum and a positive reaction of ascal plugs in Melzer's were added as new characters. Tympanis frangulae was now transferred into the genus Dermatella P.Karst. Comparison of the generic diagnoses reveals that Aleuriella also was delimited (from Dermatella) by its nonerumpent habit, 8-spored asci and medium-sized spores. In his later revision, Karsten (1885) abandoned Aleuriella and synonymized it with Mollisia. Thereafter the genus has been considered as a synonym of Mollisia.

The sole species, Aleuriella personata (P.Karst.) P.Karst., is best characterized by the ellipsoid-inequilateral spores, which frequently contain spumose material and numerous corpusculi. The contents do not stain in CB, MLZ or CR. Many spores do not stain for cytoplasm and contain just a single regular, large globule. In shape and contents the spores resemble those of Graddonia coracina Dennis. To my knowledge, such spores are not found in the genus Mollisia.

The excipular structure of $A$. personata is mollisioid with an outer layer of light brown textura angularis. Nor is the structure of the margin, with cylindrical-clavate hyphal ends, widely different from Mollisia. However, the stipitate habit and especially the curious spores make Peziza personata a quite unusual element in Mollisia. Hence, Karsten's original delimi-

Fig. 3. Aleuriella personata, lectotype (d), coll. 3362 (a, f), coll. 3363 (b, c, e, g, h), scale $50 \mu \mathrm{m}$, for apothecia $100 \mu \mathrm{m}$. $\mathrm{a}, \mathrm{b}$ ) asci and paraphyses, c) spores, d) section from margin, e) dry apothecia, f) ectal excipulum from medial flank area, g) ectal excipulum from lower flank area, h) section close to cup margin . 

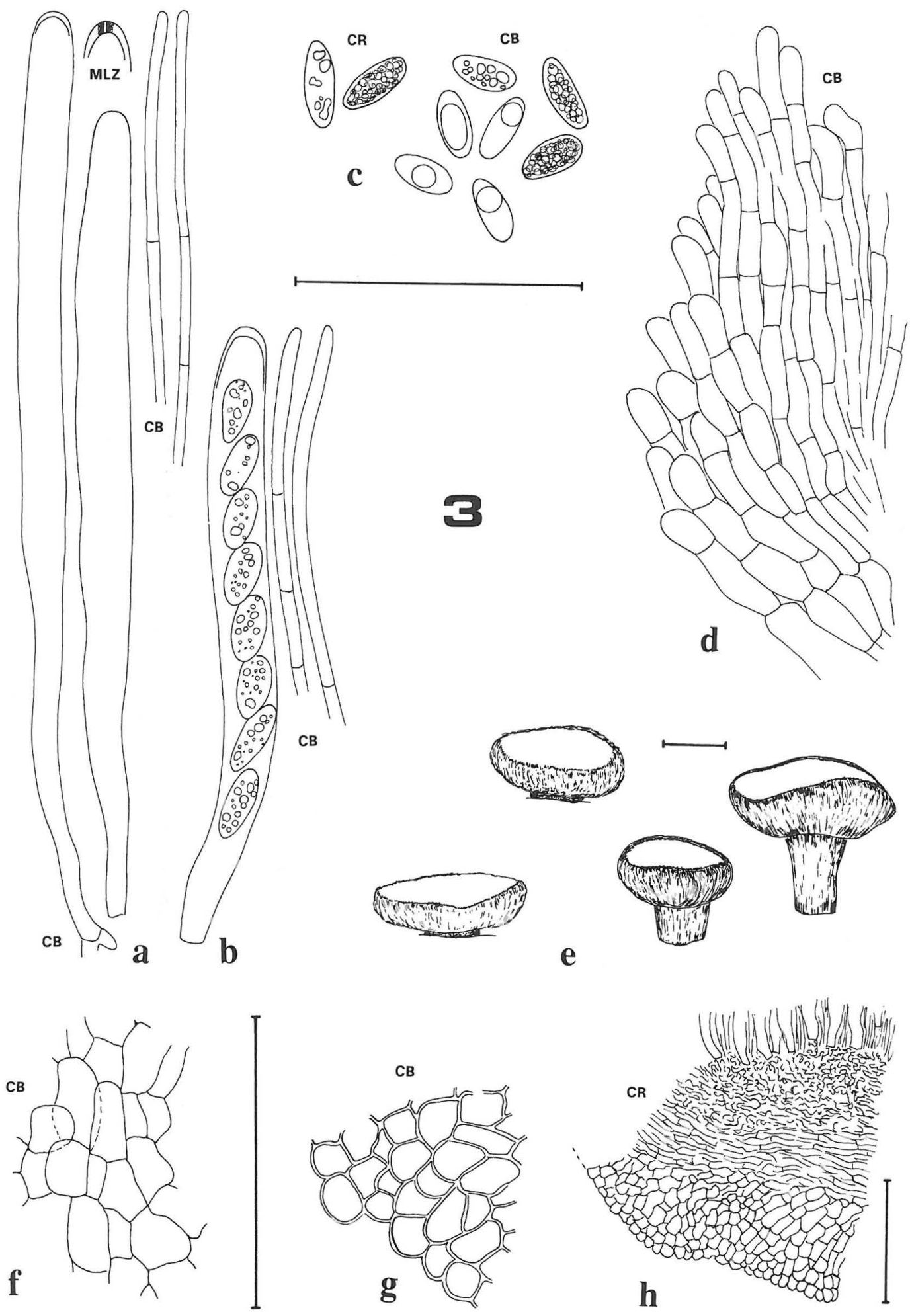
tation is here supported and the genus Aleuriella accepted for stipitate-sessile mollisioid fungi with large, spumose spores.

At first sight, the genus could also be considered to offer an earlier name for Graddonia. Except for the margin, the excipular structures are quite similar (Fig. 4). In Graddonia, unlike $A$. personata, the paraphyses contain abundant pigment, even in dry material. This pigment is most clearly seen in CR and MLZ mounts, and partially lost in heated $\mathrm{CB}$ mounts. Observations based on living, fresh material of A. personata are needed to decide on the taxonomic value of this difference. Multiguttulate paraphyses were also mentioned as typical of Graddonia by Baral (1985). The apothecia of Graddonia are always broadly sessile. The spores show one additional curious feature: they are frequently eccentrically septate.

Collections of $G$. coracina originate from deciduous wood in inundated sites (Lundqvist \& Moberg 1978, Dennis 1981, Baral 1985). The exact ecology of Karsten's specimens can not be ascertained. They occur on pieces of inner cortex of Betula. A species with similar ecology as Graddonia is Mollisia psilopezioides Svrček Material for study of this species unfortunately was not forwarded from PRM. Judging from the description it closely resembles A. personata (Svrček 1978). The broad, guttulate spores of the latter measure 9.5-14.5 × 4.8-6.8 $\mu \mathrm{m}$ (average of 25 spores in CB being $11.9 \times 5.4 \mu \mathrm{m}$ ), which is a close match to Svrček's description. Even the convex apothecia illustrated in M.psilopezioides can be found in the present material. The differencies between the two taxa lie in the more roundish excipulum, the occurrence on coniferous wood, and the clavate paraphyse apices of M. psilopezioides.

\section{Additional specimens examined}

Finland. Etelä-Häme: Tammela, Mustiala, VIII.1866 $P$. Karsten 3358 (H, syntype); 26.V.1869 P. Karsten 3359 (H); 23.VII.1869 P. Karsten 3361 (H); Mustiala, Haaran- korpi, 0l.IX.1869 P. Karsten $3360(\mathrm{H})$; Mustiala, Särkijärvi, 05.IX.1870 P. Karsten $3362(\mathrm{H})$; Mustiala, 05.VIII.1872 P. Karsten $3363(\mathrm{H})$.

\section{Peziza perforata P.Karst. - Fig. 5.}

Peziza perforata P. Karst., Fungi Fenniae Exsiccati, fasc. 6: 529. 1866. - Geopyxis perforata (P.Karst.) Sacc., Syll. Fung. 8: 73. 1889. - Galactinia perforata (P.Karst.) Boud., Hist. Classific. Discom. Europe: 47. 1907. - [Finland. Etelä-Häme:] Tammela, Mustiala, [Nokkamäki,] ad terram arenos., 5.VIII.1866 P. Karsten 3408 (H, lectotype; selected here).

The material distributed in Fungi Fenniae Exsiccati consists of a very juvenile fruit body in each set (H, K, UPS checked). The only more mature specimen is that in Karsten's personal herbarium in $\mathrm{H}$ (No. 3408). The protologue in FFE 529 is short and few of the descriptive terms are enscribed on the packet of 3408. However, since the collection date, and the ecology, match the protologue, and since the perforated stipe is present, there can be little doubt that 3408 is original, cited material.

Selecting a specimen outside FFE as lectotype may seem somewhat less logical than selecting one of the specimens distributed in FFE (bearing the protologue), but since in this case Karsten evidently kept the only mature specimen in his own herbarium, the exception is taxonomically sound. The typifications in general will be discussed in a forthcoming treatise on Karsten's herbarium.

Karsten collected this curious-looking discomycete from one locality and gave it specific rank mainly because of the perforated receptacle (Karsten 1869). The collection was distributed in his Fungi Fenniae Exsiccati accompanied with a diagnosis. $P$. perforata clearly belongs to Tarzetta (Cooke) Lambotte and with its relatively regular paraphyse apices and spores measuring 20-25. $5 \times 11-13 \mu \mathrm{m}$, it keys into $T$. catinus (Holmsk. : Fr. ) Korf \& Rogers (Dissing \& Raitviir 1974, Harmaja 1974, Senn-Irlet 1989). The asci arise from simple septa and have

Figs. 4-5. Graddonia coracina (Finland. Etelä-Häme: Tampere, Peltolammi, 29.VIII.1983 Söderholm 1001, TUR) and lectotype of Peziza perforata, scale $50 \mu \mathrm{m}$, for apothecia $1 \mathrm{~mm}$. - 4: Graddonia coracina. a) asci and paraphyses, b) spores, c) marginal hyphae, d) dry apothecia, e) ectal excipulum in section from middle flank area. — 5: Peziza perforata. a) hyphae causing the villose appearance of flanks, b) paraphyses, c) spores, d) dry apothecium. 


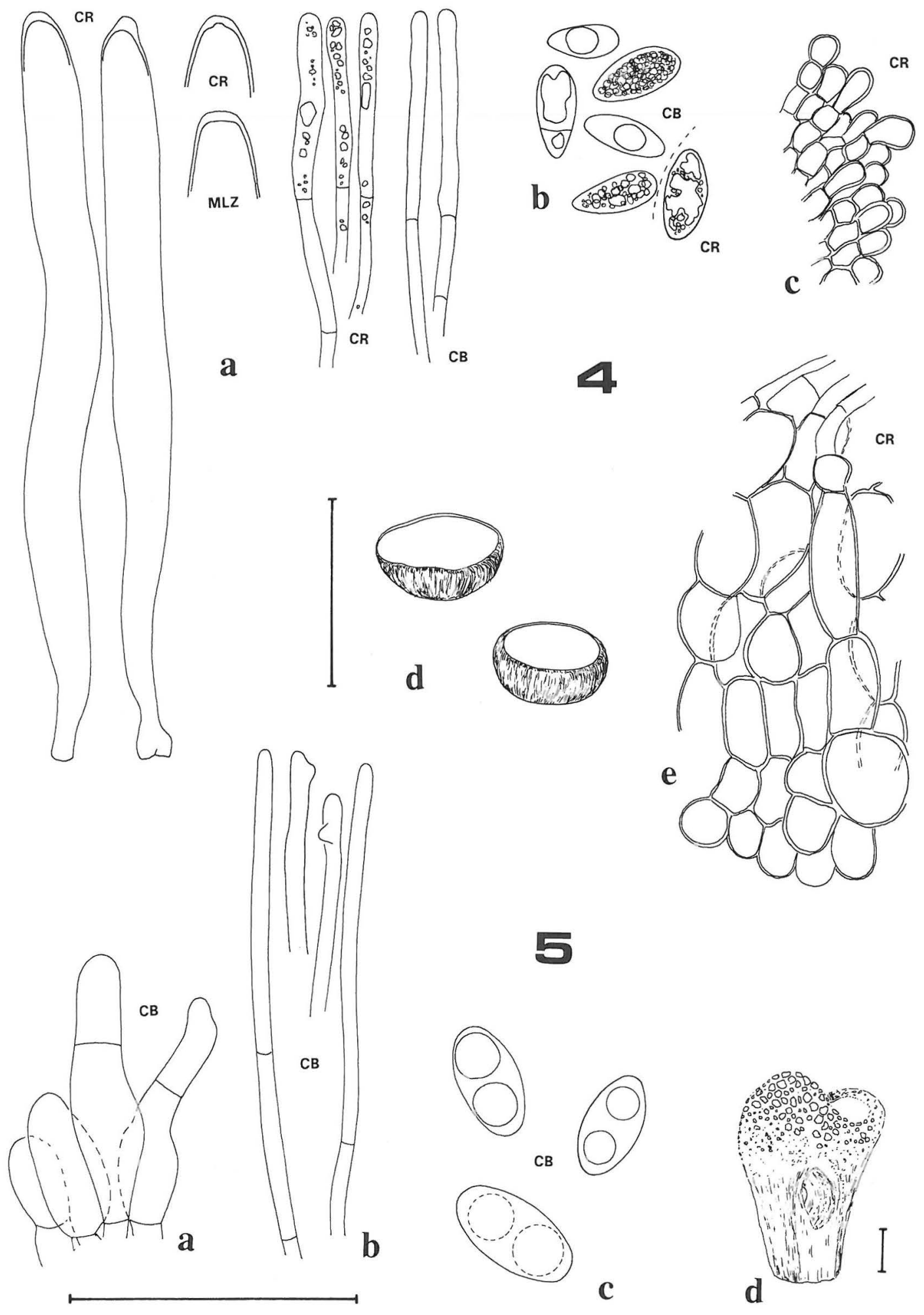


MLZ- apices, in contrast to what was stated by Karsten (1869).

Acknowledgements. Mr. H.O. Baral, Dr. Harri Harmaja and Mr. Tauno Ulvinen, Lic. Phil. are thanked for valuable comments on the manuscript. This study was financially supported by the Academy of Finland.

\section{References}

Baral, H.O. 1992: Vital versus herbarium taxonomy: Morphological differences between living and dead cells of Ascomycetes, and their taxonomic implications. - Mycotaxon 44:333-390.

Baral, H.O. \& Krieglsteiner, G.J. 1985: Bausteine zu einer Askomyzeten-Flora der Bundesrepublik Deutschland: In Süddeutschland gefundene Inoperkulate Diskomyzeten - mit taxonomischen, ökologischen, chorologischen Hinweisen und einer Farbtafel . - Beih. Z . Mykol . 6:1-160.

Clements, F.E. \& Shear, C.L. 1931: The genera of fungi. — 496 pp., 58 tab. Hafner Publishing Company. New York.

Dennis, R.W.G. 1950: Karsten's species of Mollisia. Kew Bull. 2:171-187 .

Dennis, R.W.G. 1971: New or interesting British Microfungi. - Kew Bull . 25:335-374 .

Dennis, R.W.G. 1981: British Ascomycetes. - $585+40$ pp., 44 tab. J. Cramer. Vaduz.

Dissing, H. \& Raitviir, A. 1974: Discomycetes of Middle Asia. 3. Otideaceae, Helvellaceae, Morchellaceae and Sarcoscyphaceae from the Tien-Shan Mountains. Eesti NSV Tead. Akad. Toim., Biol. 23:104-110.

Dixon, J.H. 1974: Chlorosplenium and its segregates. 1. Introduction and the genus Chlorosplenium. Mycotaxon 1:65-104.
Fries, E.M. 1823: Systema mycologicum 2. - 621 pp. Berling, Lundae.

Harmaja, H. 1974: Tarzetta pusilla n. sp. and T. spurcata (Pers.) n. comb. from Finland. - Karstenia 14:116 122.

Huhtinen, S. 1990: A monograph of Hyaloscypha and allied genera. - Karstenia 29:45-252.

Karsten, P.A. 1869: Monographia Pezizarum fennicarum. — Not. Sällsk. Fauna Flora Fennica Förh. 10:99-206.

Karsten, P.A. 1870: Symbolae ad Mycologiam fennicam. 1. - Not. Sällsk. Fauna Flora Fennica Förh. 11:211268.

Karsten, P.A. 1871: Mycologia Fennica 1. Discomycetes. - Bidr. Känned. Finlands Natur Folk. 19:1-250.

Karsten, P.A. 1885: Ascomycetum in Fennia hucusqve detectorum. Revisio monographica atque synopsis. Acta Soc. Fauna Flora Fennica 2:1-174.

Le Gal, M. 1939: Florule mycologique des Bois de la Grange et de l'Etoile. Discomycetes 2. Discales inoperculés. - Rev. Mycol. 4:25-63.

Lundqvist, N. \& Moberg, R. 1977: Discomyceter från Ångermanland. - Svensk Bot. Tidskr. 71:329-334.

Senn-Irlet, B. 1989: Discomyceten aus der alpinen Stufe der Schweizer Alpen. 2. - Beitr. Kenntnis Pilze Mitteleuropas 5:191-208.

Svrček, M. 1978: New or less known Discomycetes. 8. Nové nebo méně známé diskomycety. 8. - Česka Mykol. 32:157-160.

Svrček, M. 1987a: New or less known Discomycetes. 15. Nové nebo méně známé diskomycety. 15. - Česka Mykol. 41 16-25.

Svrček, M. 19878b: New or less known Discomycetes. 16. Nové nebo méně známé diskomycety. 16. - Česka Mykol. 41:88-96.

Received on 9 July 1993 